\title{
Management of Neonatal Priapism: Report of Two Cases and Review of the Literature
}

\section{Yenidoğan Priapizmine Yaklaşım: Iki Olgu Bildirimi ve Literatür Derlemesi}

\author{
Farhad Talibzade, Cem Akbal, Çağrı Akın Şekerci, Mehmet Özay Özgür, Haydar Kamil Çam, \\ Ferruh Şimşek
}

Marmara University Faculty of Medicine, Department of Urology, Istanbul, Turkey

\begin{abstract}
Priapism in a newborn is a rare entity with only 15 cases reported in the literature since 1879. The most commonly detected etiologic factor is polycythemia, but most of the cases are idiopathic. Conservative treatment seems to be sufficient and surgical approach is usually unnecessary. Here, we present a prolonged erection in two newborns which occurred at the first day of life and detumescence was achieved with conservative approach at the $6^{\text {th }}$ and $7^{\text {th }}$ day of life, respectively. We also reviewed the literature to investigate the most adequate evaluation and management criteria.
\end{abstract}

\section{Keywords}

Idiopathic, conservative, priapism, neonatal, management

\section{ÖZ}

Yenidoğan priapizmi nadir görülen bir hastalık olup 1879'dan şimdiye kadar literatürde 15 olgu bildirimi yapılmıştır. En sık rastlanan etiyolojik faktör polisitemi olsa da, çoğunlukla idiyopatiktir. Yenidoğan priapizmi genellikle iskemik olmayan tipte seyreder. Tedavide çoğu zaman cerrahi müdaheleye gerek kalmaz. Konservatif yaklaşım en iyi seçenek olarak görünmektedir. Bu olgu sunumunda konservatif izlem ile yaşamın 6 . ve 7. günlerinde gerileyen iki yenidoğan priapizm olgusunu sunulmaktadır. Olgu sunumu ile beraber en uygun yaklaşım ve değerlendirme için yol göstermesi amacıyla literatür derlemesi de sunulmuştur.

Anahtar Kelimeler

İdyopatik, konservatif, priapizm, yenidoğan, yaklaşım

\section{Introduction}

Preservation of normal erectile function is the major goal in the management of priapism. Ischemic priapism is a urological emergency due to compartment syndrome after 4 hours of prolonged erection. However, ischemic priapism has not yet been reported in a neonate. Priapism in newborn is challenging situation for pediatric urologists because of the lack of experience due to paucity of cases, and wellestablished guidelines. Therefore, evaluation and management strategy remains unclear. Here, we present the latest two cases of newborn priapism and review of the literature.

\section{Case Presentation}

First case was the second child of a 31-year-old woman. The newborn was delivered by cesarean section at the 39th week of gestation with a birth weight of $2870 \mathrm{~g}$. Appearance, Pulse, Grimace, Activity, Respiration (APGAR) test scores were $9 / 10$ and 9/10 at 1 and 5 minutes, respectively. There was no evidence of blood group incompatibility and hematological pathology in the newborn. Blood count, biochemical analysis, and physical examination revealed no abnormality and, neurological examination was normal. Maternal hypothyroidism, for which she used levothyroxine, and a history of smoking during pregnancy was noted. Routine prenatal examinations were performed regularly. The patient was referred to the pediatric urology department at the second day of life with prolonged erection which was noticed at the first day of life by the parents. Physical examination showed rigid penis without cyanosis and tenderness (Figure 1). The testes were descended bilaterally and normal on physical examination. Projectile voiding was observed without restlessness and, defecation was normal. Penile Doppler ultrasound scan revealed normal arterial and venous flow and there was no evidence of ischemic priapism. Polycythemia and other hematological disorders were ruled out after pediatric hematology consultation. The patient underwent conservative follow-up. Spontaneous detumescence was achieved at the $6^{\text {th }}$ day of life without any surgical intervention. His course was uneventful. No recurrence and abnormality was observed during 6 months of follow-up.

\section{Correspondence}

Cem Akbal MD, Marmara University Faculty of Medicine, Department of Urology, İstanbul, Turkey

E-mail: cakbal@gmail.com Received: 26.05.2015 Accepted: 08.06.2015 
The second case was the first child of a 28-year-old woman. The newborn was delivered vaginally at the $40^{\text {th }}$ week of gestation with a birth weight of $3280 \mathrm{gr}$. APGAR scores were 9/10 and 10/10 at 1 and 5 minutes, respectively. Routine neonatal evaluation was normal. Maternal smoking history was denied. The patient was referred to the pediatric urology department at the first day of life with prolonged erection. Physical examination showed a rigid penis without cyanosis or tenderness (Figure 1). The testes were descended bilaterally and were found to be normal on physical examination. Hematological evaluation showed no pathology. Penile Doppler ultrasound imaging was not performed for this case. Finally, the detumescence was achieved on the $7^{\text {th }}$ day of life without any surgical intervention. No recurrence and abnormality was observed during 3 months of followup.

\section{Discussion}

Priapism is rare in children, especially in neonates. Fifteen cases have been reported in the literature since $1879(1,2,3,4,5,6,7,8,9,10)$.

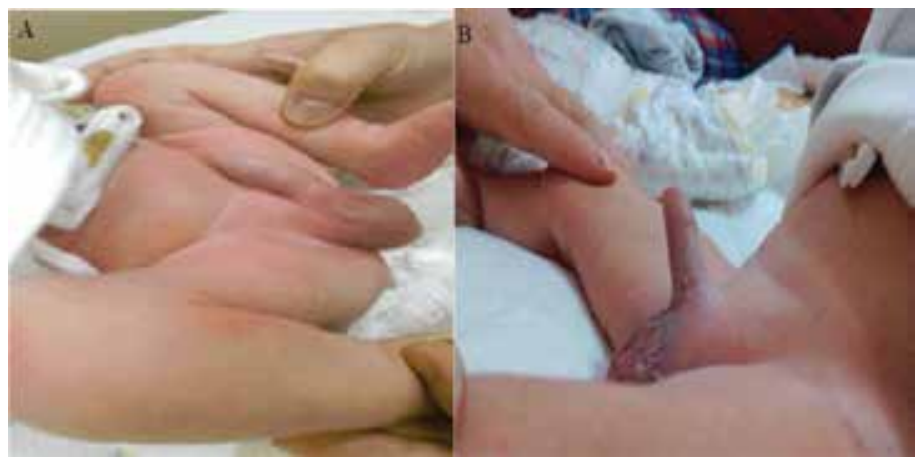

Figure 1. Prolonged penile erection of the first case at the $4^{\text {th }}$ days of life (A) and prolonged penile erection of the second case at the first day of life (B)

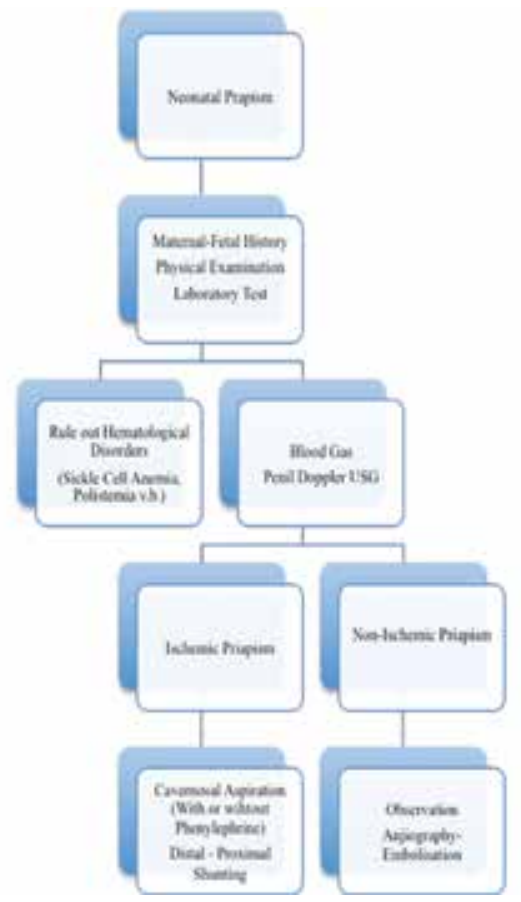

Figure 2. Algorithm of neonatal priapism management
Estimated incidence of idiopathic neonatal priapism is 15 per 100.000 live births based on a surveillance study performed between 1974 and 1988 (1). Current experience on neonatal priapism is based on mostly similar individual case reports. Thus, evaluation, treatment and followup are challenging in pediatric urology practice. We present two cases of neonatal priapism treated in our department. These cases represent our first experience on this rare disorder. Since a limited number of cases have been reported, no clinical guideline has been established for neoanatal priapism. We review the literature to propose a clinical approach for these cases (Table 1).

The most common cause for newborn pariapism is idiopathic $(8,9)$. However, other etiologic factors should be excluded. The possible causes include blood dyscrasias, malignancy, trauma, neurological pathologies and drug-related side effects (11). Although, sickle cell anemia is common in children, it is negligible in neonates because of the predominance of fetal hemoglobin. Among them, polycythemia is the most known detected etiology $(3,7)$. In the literature, there are 4 reported cases of neonatal priapism attributed to polycythemia and one to blood transfusion, where all other 10 cases were idiopathic (Table 1). Polycythemia was ruled out in our two cases and there was also no any other significant finding in evaluation. Therefore, we also defined our cases as idiopathic. We detected maternal hypothyroidism and a history of maternal smoking during pregnancy in our first case. Our management of neonatal priapism algorithm is shown in Figure 2.

Neonatal priapism was non-ischemic in all reported cases. Our two cases were also non-ischemic priapism. Increased blood flow may be the cause of priapism in cases with polycythemia. But non-ischemic course of priapism was seen in the reported 4 cases with polycythemia. We support the hypothesis of Meijer and Bakker (2) that neonatal priapism should be the form of non-ischemic priapism because this form presents with a painless erection and conservative management is possible. Therefore, Doppler ultrasound and cavernosal blood gas analysis can be reserved for cases suspicious for ischemic priapism.

Treatment of this pathology is not clear yet. Suggested management options include observation, intravenous ketamine admission, phlebotomy and exchange transfusion. Majority of cases were managed with observation, and spontaneous detumescence was achieved. However, intravenous ketamine admission in one case (3), phlebeotomy in one case and exchange transfusion in one case (4) have been reported. Intravenous ketamine admission and exchange transfusion resulted in immediate detumescence where it occurred four days after phlebotomy. In all other cases including ours, detumescence was achieved mostly in 5 to 6 days. Follow-up showed no abnormality, althought we don't have long term results. Therefore, observation should be the first approach in idiopathic neonatal priapism.

\section{Ethics}

Informed Consent: Consent form was filled out by all participants. Peer-review: Internal peer-reviewed.

\section{Authorship Contributions}

Surgical and Medical Practices: Haydar Kamil Çam, Cem Akbal, Mehmet Özay Özgür, Çağrı Akın Şekerci, Concept: Cem Akbal, Çağrı Akın Şekerci, Design: Cem Akbal, Çağrı Akın Şekerci, Data Collection or Processing: Çağrı Akın Şekerci, Farhad Talibzade, Analysis or Interpretation: Çağrı 
Table 1. Data of 17 cases [Rearranged with additional four cases from reference (2) and two cases from reference (5)]

\begin{tabular}{|c|c|c|c|c|c|}
\hline Reference & Onset & Treatment & $\begin{array}{l}\text { Duration of priapism } \\
\text { (days) }\end{array}$ & Proposed etiology & Follow up \\
\hline \multirow[t]{2}{*}{ Humbert et al. (12) } & Day 1 & Observation & 2 & Polycythemia & Normal \\
\hline & Day 4 & Phlebotomy & 5 & Polycythemia & Normal \\
\hline Larocque and Cosgrove (6) & Not reported & Observation & 4 & Polycythemia & Not reported \\
\hline Amlie et al. (7) & Day 37 & Observation & 12 & Blood transfusion & Normal \\
\hline Leal et al. (8) & At birth & Observation & 6 & Idiopathic & Normal \\
\hline Shapiro (9) & At birth & Observation & 3 & Idiopathic & Not reported \\
\hline \multirow[t]{4}{*}{ Merlob and Livne (1) } & At birth & Observation & 6 & Idiopathic & Normal \\
\hline & Day 1 & Observation & 5 & Idiopathic & Normal \\
\hline & Day 5 & Observation & 4 & Idiopathic & Normal \\
\hline & Day 1 & Observation & 5 & Idiopathic & Normal \\
\hline Stothers and Ritchie (10) & At birth & Intravenous ketamine & 3 & Idiopathic & Normal \\
\hline Walker and Casale (3) & At birth & Exchange transfusion & 4 & Polycythemia & Normal \\
\hline Meijer and Bakker (2) & Day 1 & Observation & 4 & Idiopathic & Normal \\
\hline Burgu et al. (4) & Day 1 & Observation & 3 & Idiopathic & Normal \\
\hline Aktoz et al. (5) & Day 1 & Observation & 4 & Idiopathic & Normal \\
\hline Marmara & Day 1 & Observation & 6 & Idiopathic & Normal \\
\hline Marmara & Day 1 & Observation & 7 & Idiopathic & Normal \\
\hline
\end{tabular}

Akın Şekerci, Farhad Talibzade, Literature Search: Çağrı Akın Şekerci, Farhad Talibzade, Writing: Farhad Talibzade. Conflict of Interest: No conflict of interest was declared by the authors. Financial Disclosure: The authors declared that this study has received no financial support.

\section{References}

1. Merlob P, Livne PM. Incidence, possible causes and followup of idiopathic prolonged penile erection in the newborn. J Urol 1989;141:1410-1412.

2. Meijer $B$, Bakker $\mathrm{HH}$. Management of priapism in the newborn. Urology 2003;61:224.

3. Walker JR, Casale AJ. Prolonged penile erection in the newborn. Urology 1997;50:796-799.

4. Burgu B, Talas H, Erdeve 0, Karagol BS, Fitoz S, Soygur TY. Approach to newborn priapism: a rare entity. J Pediatr Urol 2007;3:509-511.
5. Aktoz T, Tepeler A, Gundogdu EO, Ozkuvanci U, Muslumanoglu AY. Priapism in the newborn: management and review of literature. Andrologia 2011;43:65-67.

6. Larocque MA, Cosgrove MD. Priapism: a review of 46 cases. J Urol 1974;112:770-773.

7. Amlie RN, Bourgeois B, Huxtable RF. Priapism in preterm infant. Urology 1977;9:558-559.

8. Leal J, Walker D, Egan EA. Idiopathic priapism in the newborn. J Urol 1978;120:376.

9. Shapiro SR. Idiopathic priapism in the newborn. J Urol 1979;121:838.

10. Stothers L, Ritchie B. Priapism in the newborn. Can J Surg 1992;35:325326.

11. Burnett AL, Bivalacqua TJ. Priapism: current principles and practice. Urol Clin North Am 2007;34:631-642, viii.

12. Humbert JR, Abelson $H_{1}$, Hathaway WE, Battaglia FC. Polycythemia in small for gestational age infants. J Pediatr 1969;75:812-819. 